\title{
SUSTAINABLE WATER RESOURCES MANAGEMENT THROUGH THE USE OF GIS TECHNOLOGIES
}

\author{
I. MOURATIDIS ${ }^{1, *}$ \\ G. DIMOPOULOS ${ }^{2}$ \\ T. ASTARAS ${ }^{2}$ \\ S. SAVVIDIS ${ }^{3}$
}

\author{
${ }^{1}$ Technological Research Institute of West Macedonia \\ 50100 Kila Kozani, Greece \\ ${ }^{2}$ Department of Geology, Aristotle University of Thessaloniki \\ 54124 Thessaloniki, Greece \\ ${ }^{3}$ Department of Geotechnology and Environmental Engineering \\ Technological Institute of West Macedonia \\ 50100 Kila Kozani, Greece
}

Received: 03/11/08

Accepted: $30 / 06 / 10$ *to whom all correspondence should be addressed: e-mail: ilmouratid@gmail.com

\begin{abstract}
The increasing water demand, the prolonged drought periods and the human influence in natural resources that put in danger the quantity and quality of water resources, highlight the importance for rational management and exploitation of water resources in terms of sustainable development of an area. The purpose of this study is the application of procedures for sustainable management and development of the water resources of the Grevenitis basin, using Geographic Information Systems (GIS) technology. Grevenitis drainage basin is part of the greater Aliakmon river drainage basin (NW Greece). It's located in the central section of Mesohellenic Trough. The study reveals the capability of itself-reliance of the area of Grevenitis basin in covering the total water needs and the new perspectives for sustainable development of the area with the exploitation of the surface waters of Grevenitis river and the groundwater of the aquifer formed in the Plio-Pleistocene sediments, which overlay on the impermeable molassic sediments. It's also shown the important contribution of GIS technology with the creation of databases for the continuous monitoring of the various parameters with their changes and the convenience for direct drawing of thematic maps. The evaluation of quality parameters of drinking water brings to light useful results and recommendations in order to assist and improve current water quality monitoring and protective actions.
\end{abstract}

KEYWORDS: Water Resources Management, Sustainable Growth, Geographic Information Systems, Grevenitis River, Mesohellenic Trough.

\section{INTRODUCTION}

Water is one of the most important renewable natural resources.

By the term "exploitation of a region's water resources" we refer to the activities that aim in rational exploitation of these resources within the quantity limits of the annual fluctuation of water resources and in combination with works and activities with the lowest cost possible, not only financially but also environmentally (Dimopoulos, 1998; European Community (EC), 2000; Georgotas 1983; Hellenic Legislation (HL), 2007, 2003, 1987 and 1986; Kallergis, 1986; Stournaras, 2006).

The aim of the present study is the examination of the hydrogeological conditions and of the total water needs, the processing and the composition of the data, so as to come up with an integrated plan for the development of water resources of the Grevenitis drainage basin, which will contribute to sustainable growth of the area (Fig. 1). There is an attempt to analyze the procedures and the supervisory thematic maps, using GIS for direct process of hydrologic, hydrogeological and other data used in rational exploitation of water resources.

Despite the fact that the hydrologic basin of Grevenitis is mostly covered by impervious molassic formations, the important Plio-Pleistocene sediment's aquifer in the eastern part of the area, offers new perspectives for development. The development perspectives of the area are focused on the 
agricultural field, the development of winter tourism in ski resorts and on other alternative forms of tourism (Hellenic Ministry for Environment and Public Works (HMEPW), 2003; Region of West Macedonia (RWM), 2001). Furthermore, these perspectives are directly connected and emphasize the importance of the prompt and rational exploitation plan of the area's water resources

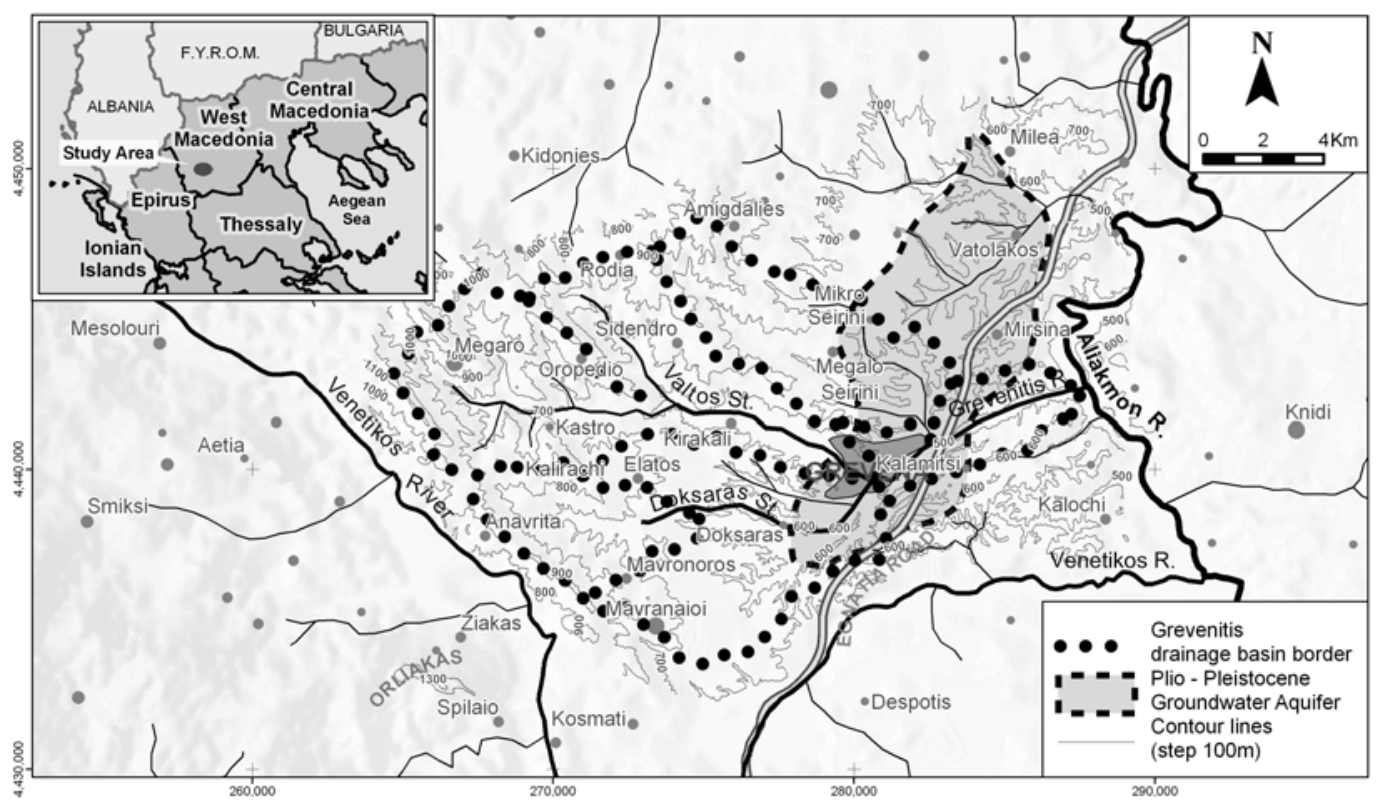

Figure 1. Location map of the study area

\section{METHODOLOGY}

Firstly it was conducted the collection and study of related bibliography, papers, essays, legislation and data concerning the study area (maps, demographic, hydrologic, climatic, drills, water quality analysis, water consumption). Then followed the field research so as to measure and record the relevant geological, hydrogeological and water resources management parameters of the area.

The next step includes the examination of the demographic data, morphological relief and drainage network, the estimation of the rainfall - altitude relation and of hydrological balance equation, the examination of geological and hydrogeological data, the hydraulic parameters of the aquifer, the determination of the daily and annual consumption of water, the determination of water chemical characteristics, the comparative examination between the today's and the future's balance of water supply and water needs, the level of exploitation of surface and underground water and the compilation of the rational exploitation plan of the water resources which contributes to sustainable growth of the area.

Databases and thematic maps were created using GIS ARC/INFO (ESRI, 1994 \& 2004; Mitchell, 1999; Zeiler, 1999) and AUTOCAD programs, while MS EXCEL program was used for tables and diagrams and HYDROPOINT program for water chemical analyses data process.

\section{GEOMORPHOLOGIC - HYDROLOGIC DATA}

Grevenitis basin is part of the greater Aliakmon river drainage basin. It has a surface of $180.24 \mathrm{~km}^{2}$. The population of the area comes up to 14,855 citizens (2001 census) and covers $40.9 \%$ of the population of Grevena Prefecture. The population is estimated to 16,243 citizens for 2007 and to 17,990 citizens for 2015 . The area includes 16 villages and the city of Grevena $(70.3 \%$ of the total population) (Fig. 1).

The geomorphologic study of the area reveals its bold relief and the high energy potential of Grevenitis drainage basin. The local relief $(H)$ is $719 m$ (Astaras, 1980), while the relief ratio $(\mathrm{Rh})$ is $3.13 \%$ (Schumm, 1956; Astaras, 1980) and shows the intensive degree of erosion processes of the basin (Strahler, 1964). The average altitude $\left(\mathrm{H}_{\mathrm{m}}\right)$ was estimated to $695.92 \mathrm{~m}$ using the relation $\mathrm{H}_{\mathrm{m}}=$ $\sum\left(\mathrm{S} \bullet \mathrm{H}_{\mathrm{m}}\right) / \mathrm{E}$ (Wister \& Brater, 1965 by Kallergis 1973), while the average ground slope $(\beta)$ was estimated to $25 \%$ using the relation $\tan \beta=\left(\mathrm{dh} \cdot \sum \mathrm{L}\right) / \mathrm{P}$ (Astaras, 1980). The hypsometric integral was estimated to $\int=47.9 \%$, and shows the mature stage of denudation of the basin (Strahler, 1952; Astaras, 1980). In terms of Howard's (1967) classification the drainage network of the study area 
has a "dendritic pattern", showing the homogeneity of the area's petrologic composition and the runoff preponderance over water infiltration (Howard, 1967; Astaras, 1988). The main bed-river of Grevenitis is characterized as $6^{\text {th }}$ class, while the bifurcation ratio (Rb) is 3.73 showing the superiority of runoff compared to water infiltration (Strahler, 1952; Horton, 1945; Astaras, 1980).

Table 1. Main Geomorhologic Features of Grevenitis Basin

\begin{tabular}{|l|l|}
\hline Surface & $180.24 \mathrm{~km}^{2}$ \\
\hline Population & $14,855(2001), 40.9 \%$ of Grevena Prefecture population \\
\hline Local Relief $(\mathrm{H})$ & $719 \mathrm{~m}$ \\
\hline Relief Ratio $(\mathrm{Rh})$ & $3.13 \%$ \\
\hline Average Altitude $\left(\mathrm{H}_{\mathrm{m}}\right)$ & $695.92 \mathrm{~m}$ \\
\hline Average Ground Slope $(\beta)$ & $25 \%$ \\
\hline Hypsometric Integral $\left(\int\right)$ & $47.9 \%$ \\
\hline $\begin{array}{l}\text { Drainage Network } \\
\text { (Howard's Classification) }\end{array}$ & Dendritic pattern \\
\hline $\begin{array}{l}\text { Main bed-river } \\
\text { Classification }\end{array}$ & $6^{\text {th }}$ class \\
\hline Bifurcation Ratio $(\mathrm{Rb})$ & 3.73 \\
\hline
\end{tabular}

The climate of the study area is characterized from the change of Mediterranean to Continental climate of Balkans (Livadas, 1979; Balafutis, 1977). According to the process of data available from 19 rain gauge stations of the area (Hellenic Ministry for Industry, Energy and Technology (HMIET), 1987), there was calculated the precipitation $(P)-$ altitude $(H)$ relation: $P=0.61 \mathrm{H}+342.97 \mathrm{~mm}$ of rain. The average annual precipitation was estimated to $P_{0}=771.89 \mathrm{~mm}$ of rain, while the overall annual volume of precipitation in Grevenitis basin was estimated to $V_{p}=139.13 \times 10^{6} \mathrm{~m}^{3}$ of water. The average annual runoff estimated to $V_{R}=34.78 \times 10^{6} \mathrm{~m}^{3}$ (25\% of the annual precipitation). The average annual actual evapotranspiration using the method Thornthwaite \& Mather (1955 \& 1957) was estimated to $V_{E}=88.03 \times 10^{6} \mathrm{~m}^{3} \quad(63.27 \%$ of the annual precipitation). The average annual infiltration estimated to $V_{I}=16.32 \times 10^{6} \mathrm{~m}^{3}(11.73 \%$ of the annual precipitation). This amount refers to the water recharging the Plio-Pleistocene aquifer and regulates the amount of water that can be pumped annually from this aquifer (Mouratidis, 2005).

Table 2. Average Annual Hydrologic Balance of Grevenitis Basin

\begin{tabular}{|ll|rl|l|}
\hline Precipitation & $\left(\mathrm{V}_{\mathrm{P}}\right)$ & $\mathbf{1 3 9 . 1 3 \times 1 0 ^ { 6 }}$ & $\mathrm{m}^{3}$ & $\left(\% \mathrm{~V}_{\mathrm{P}}\right)$ \\
\hline Runoff & $\left(\mathrm{V}_{\mathrm{R}}\right)$ & $34.78 \times 10^{6}$ & $\mathrm{~m}^{3}$ & 25.00 \\
\hline Actual Evapotranspiration & $\left(\mathrm{V}_{\mathrm{E}}\right)$ & $88.03 \times 10^{6}$ & $\mathrm{~m}^{3}$ & 63.27 \\
\hline Infiltration & $\left(\mathrm{V}_{\mathrm{I}}\right)$ & $16.32 \times 10^{6}$ & $\mathrm{~m}^{3}$ & 11.73 \\
\hline
\end{tabular}

\section{GEOLOGICAL DATA}

The study area consists part of Mesohellenic Trough, which is located in the geological area between the Sub-Pelagonian Zone and the Zone of Pindos (Mountrakis, 1985). The geological formations of the area are:

- The molassic sediments of Tsotili and Pentalofos formations (successions of conglomerates, sandstones, marls and marl sandstones) of Lower Miocene with total depth of about $6.2 \mathrm{Km}$.

- The Plio-Pleistocene sediments consisted of loose conglomerates, clays, sands, and loose sandstones with total depth of $200 \mathrm{~m}$ approximately, which overlay with discordance the molassic sediments.

- The Holocene alluvial deposits of few meters depth, which cover the riverbeds (Brunn, 1956; Mountrakis, 1985; Savoyat \& Monopolis, 1972; Mavridis \& Kelepertzis, 1993).

Molassic sediments cover $62 \%$, Plio-Pleistocene sediments $29.2 \%$ and alluvial deposits the $8.8 \%$ of the study area's total surface (Fig. 2).

The molassic sediments are not folded, but they present Eastward slopes, as a result of the tectonic movements since Miocene (Vamvaka et al., 2004). Few faults with NE-SW direction are found in molassic sediments (Savoyat \& Monopolis, 1972; Mavridis \& Kelepertzis, 1993). 


\section{HYDROGEOLOGICAL DATA}

There are 35 springs in Plio-Pleistocene sediments with constant flow and low average water yield $\left(15.7-25.9 \mathrm{~m}^{3} \mathrm{~d}^{-1}\right)$. In molassic sediments occur 64 springs with constant flow and low average water yield $\left(10.9-23.6 \mathrm{~m}^{3} \mathrm{~d}^{-1}\right)$ (Fig. 2).

The most important permeable formation is that of the Plio-Pleistocene sediments, where the unconfined aquifer system has been created, overlying the molassic impermeable basement (Stamos \& Zampokas, 1995; Mouratidis, 2005) (Figs. 2,3). In the area of the aquifer there have been drilled 31 wells. The process of the available data mainly from the geological profiles of the wells and the field measurements of the piezometric surface of the aquifer during the period $2002-2006$ shows that:

- The total surface of the aquifer comes up to $61 \mathrm{~km}^{2}$ approximately.

- The groundwater layers that develop in loose conglomerates, sandstones and marl sandstones interchange with the impermeable clay sediments.

- The average thickness of groundwater layers is considered to be about $45-50 \mathrm{~m}$ in central parts and about $15 \mathrm{~m}$ in peripheral parts of the aquifer.

- The maximum total thickness of groundwater layers was drilled in the areas of Elefthero and Grevena (EL2-63m, GR5-62m), while the minimum SW of Grevena (GR6-23m).

- The maximum average depth of the molassic basement comes up to $120-140 \mathrm{~m}$, while the maximum depth was met in wells GR1-124m, EL8 \& BA4-159m.

- The average yield of the wells ranges from 50 to $100 \mathrm{~m}^{3} \mathrm{~h}^{-1}$.

- In Grevena area appear the highest yields up to 80-100 $\mathrm{m}^{3} \mathrm{~h}^{-1}$ (GR1, GR2, GR4, GR5).

- In Elefthero and Vatolako area appear the medium yields up to $40-60 \mathrm{~m}^{3} \mathrm{~h}^{-1}$ (EL1-EL8, VA1VA5).

- In Mikro and Megalo Seirini area appear the lower yields up to $20 \mathrm{~m}^{3} \mathrm{~h}^{-1}$ (MS2, MIS1, MIS3).

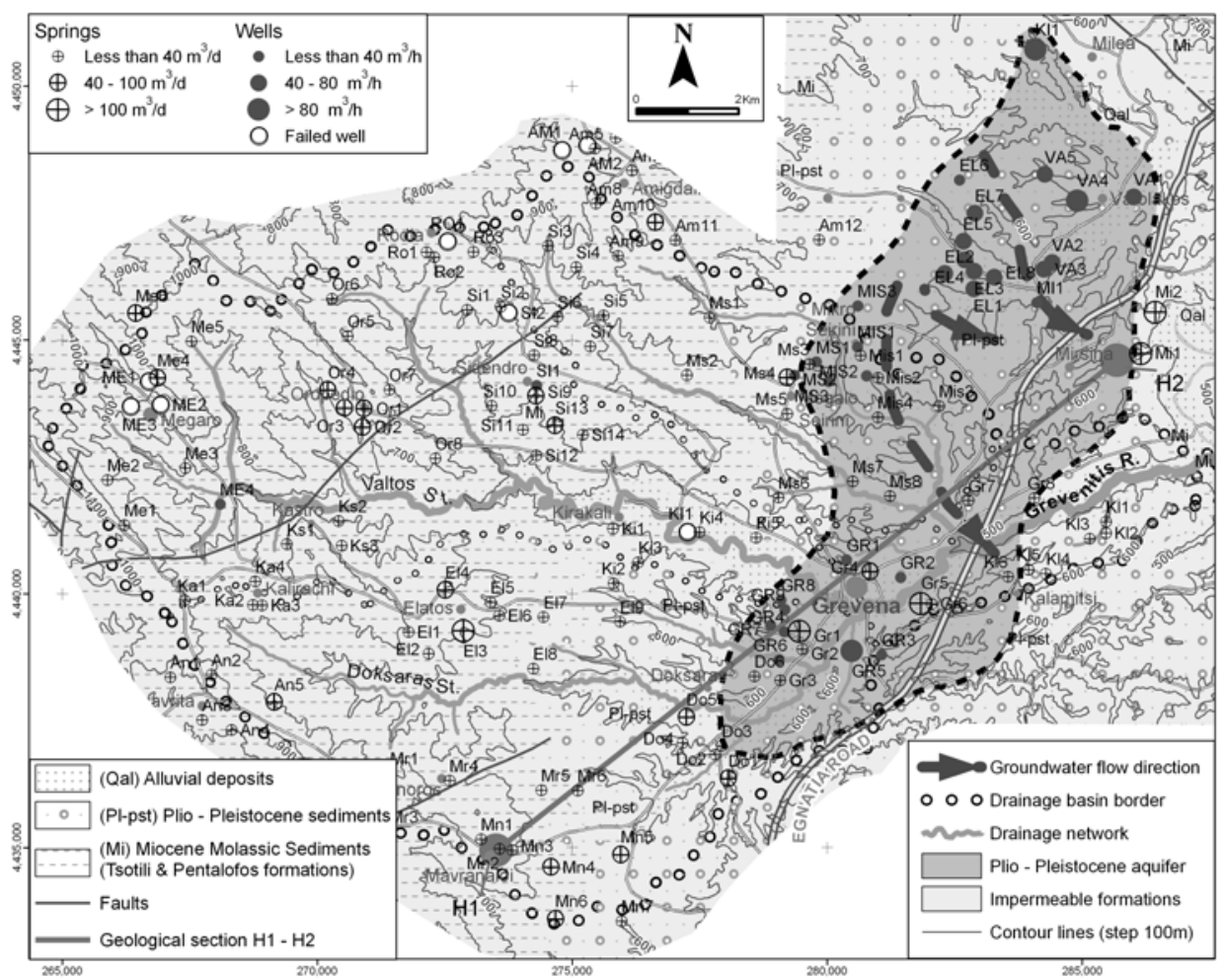

Figure 2. Hydrogeological map of Grevenitis river basin 


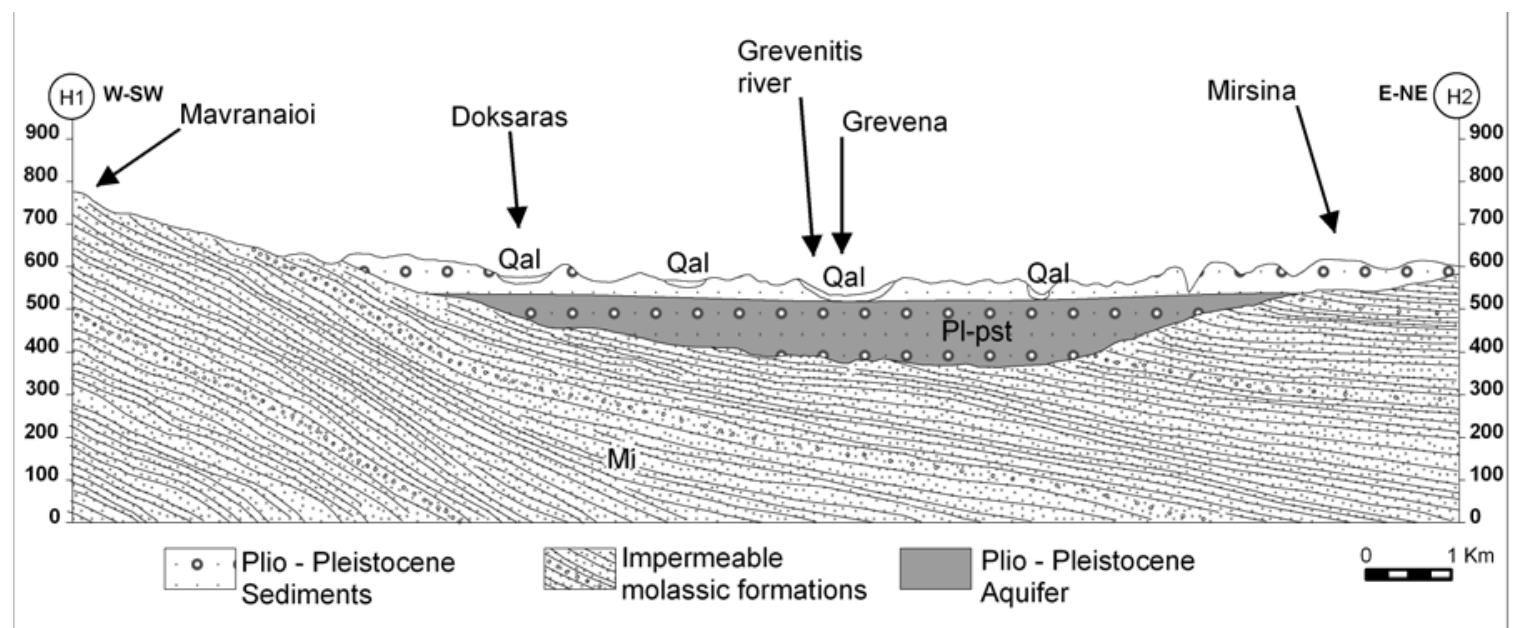

Figure 3. Hydrogeological section $\mathrm{H}_{1}-\mathrm{H}_{2}$ of Grevenitis basin

According to the method of Cooper \& Jacob (1946), the transmissibility coefficient is equal to $T=$ $2.07 \times 10^{-3} \mathrm{~m}^{2} \mathrm{~s}^{-1}$, the permeability coefficient is equal to $\mathrm{k}=3.34 \times 10^{-5} \mathrm{~m} \mathrm{~s}^{-1}$ and the specific well capacity is equal to $\mathrm{Qs}=11.44 \mathrm{~m}^{2} \mathrm{~h}^{-1}$ or $3.17 \times 10^{-3} \mathrm{~m}^{2} \mathrm{~s}^{-1}$ (Dimopoulos, 2007 \& 1995; Soulios, 2001). The above numbers are indicative of the high level of water capacity of the Plio-Pleistocene aquifer. The hydraulic gradient of the aquifer has high values in northern part (10-20\%) and low values in central and southern part (2-3\%o).

Generally, the groundwater flow direction is NNW - SSE. The total groundwater reserve of the aquifer comes up to $\mathrm{R}=380 \times 10^{6} \mathrm{~m}^{3}$ of water (Mouratidis, 2005; Dimopoulos, 1995). The average annual volume of water that recharges the Plio-Pleistocene aquifer comes up to $17.7 \times 10^{6} \mathrm{~m}^{3}$ of water (Mouratidis, 2005).

The results of the water chemical analyses show that both Grevenitis surface water and PlioPleistocene groundwater aquifer are of good quality (Stamos et al., 2001). The waters of the area belong to be the "average hard" waters with total hardness of 8.3-23.6 ${ }^{\circ} \mathrm{dH}$ (Dimopoulos, 2007 \& 1995).

The low percentage of alkalinity (3.19-32.38\%) and the Ayer (1975) water quality parameters make these waters appropriate for irrigation. According to the irrigation water classification diagrams based on SAR and conductivity (US Salinity Laboratory, 1954), the waters are classified in low Sodium class (S1) and in medium conductivity class (C2).

The examined chemical parameter values of 21 samples of drinking water are in general lower than parametric values suggested by legislation and science for the water intended for human consumption, with the exception of the values of $\mathrm{Mg}^{2+}$ in surface waters and $\mathrm{Mg}^{2+}, \mathrm{Mn}^{2+}$ and $\mathrm{F}^{-}$in groundwater, which are barely higher from the maximum limits permitted (EC, 1998; HL, 2001; US Environmental Protection Agency (USEPA), 2006; US Public Health Service (USPHS), 1962; World Health Organization (WHO), 1993; Dimopoulos, 1995; Kalergis, 1986).

Almost all the communities have realized some microbiological analyses of the drinking water. Frequent microbiological analyses on a regular basis (once a month) exist only in Municipality of Grevena. From the 379 total samples of microbiological analyses, 283 gave positive results concerning the suitability of drinking water ("safe" water). In the rest 96 samples $(25.3 \%$ of total samples) there is a slight problem of microbiological load. In most of them the number of the coliforms reaches 10 per $100 \mathrm{ml}$ of water. Although disinfection is of unquestionable importance in the supply of safe drinking-water, only four communities (Grevena, Kalamitsi, Kirakali, Amigdalies) make chlorination of drinking water using semi-automatic chlorinators (dose-measuring pumps).

The actions performed from local authorities towards the protection of the drinking water quality include mainly the water supply system checking, some control of drinking water sources areas, and the replacement and improvement of water supply systems.

In several areas near the drinking water springs and wells of the study area, there have been observed several human activities (free waste deposition areas, cemeteries, sucking tanks, land fertilization and other activities), which could constitute major pollution sources for the water of the springs (Kirakali, Megaro, Oropedio, Kalamitsi, etc), and necessitate the implementation of a protection plan for drinking water resources (Dimopoulos, 2007 \& 1995; WHO, 2006; Tsakiris, 1995; Antonopoulos, 1993; Kallergis, 1986; Davis \& DeWiest, 1967). 


\section{WATER CONSUMPTION DATA}

The total water needs in an average annual basis come up to $2.9 \times 10^{6} \mathrm{~m}^{3}(2007)$ and to $6.0 \times 10^{6} \mathrm{~m}^{3}$ for the year 2015 (Table 3).

The total, annual drinking water needs come up to $2.11 \times 10^{6} \mathrm{~m}^{3}(2007)$ and are expected to increase up to $2.33 \times 10^{6} \mathrm{~m}^{3}$ in 2015 . The annual drinking water needs include:

- The drinking water needs of the residents,

- The household water needs,

- The irrigation needs for small gardens,

- The water needs for the domestic animals,

- The water needs for the small enterprises and

- The water supply network leakages estimated up to $15 \%$ of the total drinking water needs.

Grevena city appears to have the highest water needs $(76 \%)$. Today the total water supply per year is $2.86 \times 10^{6} \mathrm{~m}^{3}(81.2 \%$ derives from the springs outside of Grevenitis basin (Aetia, Smiksi, Filippaioi and Orliakas), $2.5 \%$ from springs inside the basin and $16.3 \%$ from wells).

Table 3. Annual balance of water resources and water needs of Grevenitis basin area $\left(x 10^{3} \mathrm{~m}^{3}\right)$

\begin{tabular}{|l|r|l|r|r|}
\hline \multicolumn{2}{|c|}{ Water Resources } & \multicolumn{1}{c|}{ Water Needs } & \multicolumn{1}{c|}{$\mathbf{2 0 0 7}$} & \multicolumn{1}{c|}{$\mathbf{2 0 1 5}$} \\
\hline Surface Water & 34,781 & $\begin{array}{l}\text { Residential Water } \\
\text { Needs }\end{array}$ & 2,107 & 2,337 \\
\hline Groundwater & 16,319 & Irrigation & 509 & 3,390 \\
\hline $\begin{array}{l}\text { Springs outside of } \\
\text { Grevenitis Basin }\end{array}$ & 4,192 & Industrial Needs* & 0 & 0 \\
\hline & Energy & 344 & 344 \\
\hline Total & $\mathbf{5 5 , 2 9 2}$ & Total & $\mathbf{2 , 9 6 0}$ & $\mathbf{6 , 0 6 1}$ \\
\hline
\end{tabular}

${ }^{*}$ Included in residential water needs

The total drinking water needs come up to $3.32 \times 10^{3} \mathrm{~m}^{3} \mathrm{~d}^{-1}$ during winter and to $8.27 \times 10^{3} \mathrm{~m}^{3} \mathrm{~d}^{-1}$ during summer season. Being an agricultural region, justifies the high rate of water for irrigation needs $(48 \%)$ of the gardens during summer period. This is the most important reason for the high daily consumption of water (300 lit per person).

During winter period all residential districts are able to cover their water needs. During summer period 11 villages are barely able to cover their needs, while Grevena, Doksaras, Kalamitsi, Amigdalies, Mikro and Megalo Seirini cover their water needs from wells. Those 11 villages (Elatos, Kastro, Kirakali, Rodia, Sidendro, Kalirahi, Megaro, Oropedio, Anavrita, Mavranaioi and Mavronoros) need to increase their water supply, so as to cover their total water needs during the summer period. The total amount of water shortage in summer period comes up to $240 \mathrm{~m}^{3} \mathrm{~d}^{-1}$ or $10 \mathrm{~m}^{3} \mathrm{~h}^{-1}$ (Fig. 4). The average annual amount of water consumed in irrigation for agricultural cultivations (corn, clover, vegetables and fruit-bearing trees) of $0.75 \mathrm{Km}^{2}$ area come up to $508,500 \mathrm{~m}^{3} \mathrm{y}^{-1}$ (Kirakali, Grevena, Megalo and Mikro Seirini). An important part of this amount of $237,300 \mathrm{~m}^{3} \mathrm{y}^{-1}$ derives from Grevenitis river, while the rest part of $271,200 \mathrm{~m}^{3} \mathrm{y}^{-1}$ from the Plio-Pleistocene aquifer. It is estimated that the irrigation area could be increased more than $5 \mathrm{Km}^{2}$ in 2015 corresponding to an average annual irrigating water needs of more than $3.4 \times 10^{6} \mathrm{~m}^{3} \mathrm{y}^{-1}$. 


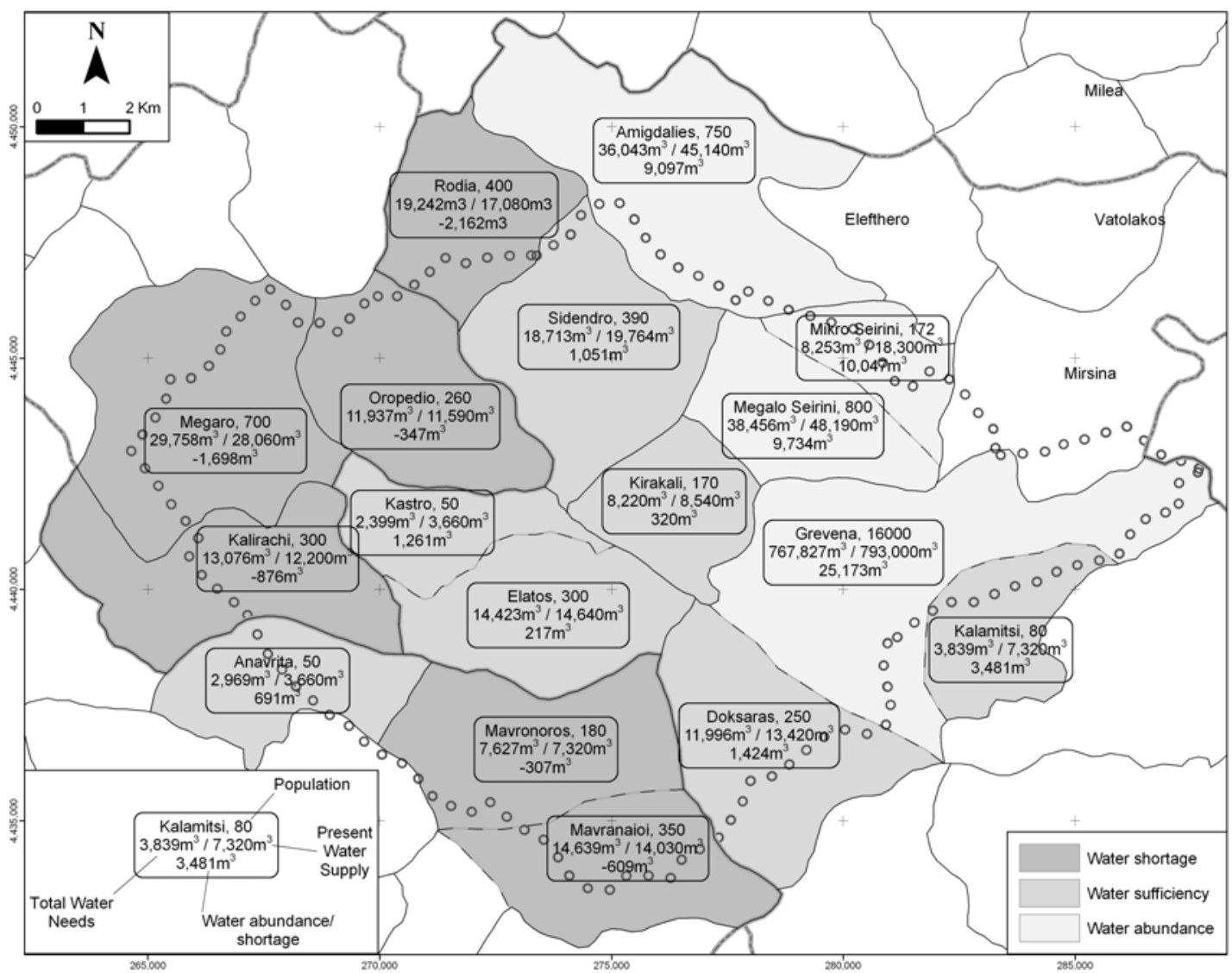

Figure 4. Drinking water balance per community for summer period

The industrial needs of water concerning the small enterprises of the area are included in residential water needs mainly of Grevena city.

There is no need of water for energy production or energy storage matters.

The minimum annual volume for recreational needs of Grevenitis River is estimated to $344.077 \mathrm{~m}^{3}$ of water.

\section{RATIONAL EXPLOITATION PLAN OF WATER RESOURCES}

The plan for the rational exploitation of Grevenitis basin water resources is based on the examination of the present and the future balance between the water supply and the water needs. Furthermore, it is examined the extend of exploitation of both surface and groundwater waters of the area in relation to the water needs that exist today and in the future and suitable proposals are made in order to achieve an optimum level of water resources exploitation (quantitative and qualitative) (Kallergis, 1986; Dimopoulos, 1995; Soulios, 2004; Stournaras, 2006).

The average annual total amount of water in the area of Grevenitis basin (springs inside and outside the area, surface and groundwater waters) comes up to $55.29 \times 10^{6} \mathrm{~m}^{3}$ (Table 3). It is important the fact that this amount of water is much greater than total water needs. Furthermore, it is important to notice that the total water needs can also be covered by the amount of the groundwater of the PlioPleistocene aquifer.

After correlating the data for the available amount of water supply and the water needs, the alternative proposals are being suggested for each residential district to cover totally the present and future water needs (Table 4 and Figure 5).

It is very important to notice the relative low cost of those alternative proposals, which is estimated from $40,000 €$ to $70,000 €$ for the options that include exploitation of springs and from $80,000 €$ to $150,000 €$ for the options that include construction of wells according to the local conditions. 
Table 4. Alternative proposals for covering the total water needs per residential district

\begin{tabular}{|c|c|c|c|}
\hline No & $\begin{array}{l}\text { Residential } \\
\text { District }\end{array}$ & $1^{\text {st }}$ Alternative Option & $2^{\text {nd }}$ Alternative Option \\
\hline 1 & Grevena & $\begin{array}{l}\text { Enrichment of domestic water supply } \\
\text { from Aetia springs (Stamos, 2001) }\end{array}$ & $\begin{array}{l}\text { Well construction in Plio-Pleistocene } \\
\text { aquifer (for Grevena - Kalamitsi common } \\
\text { supply) }\end{array}$ \\
\hline 2 & Doksaras & $\begin{array}{l}\text { Enrichment of domestic water supply } \\
\text { from Aetia springs and/or Do5 spring }\end{array}$ & $\begin{array}{l}\text { Well construction in Plio-Pleistocene } \\
\text { aquifer }\end{array}$ \\
\hline 3 & Kalamitsi & $\begin{array}{l}\text { Enrichment of domestic water supply } \\
\text { from Aetia springs }\end{array}$ & $\begin{array}{l}\text { Well construction in Plio-Pleistocene } \\
\text { aquifer (for Grevena - Kalamitsi common } \\
\text { supply) }\end{array}$ \\
\hline 4 & Amigdalies & $\begin{array}{l}\text { Well construction in Plio-Pleistocene } \\
\text { aquifer }\end{array}$ & $\begin{array}{l}\text { Enrichment of domestic water supply from } \\
\text { Am10 and Am11 springs }\end{array}$ \\
\hline 5 & Elatos & $\begin{array}{l}\text { Enrichment of domestic water supply } \\
\text { from Aetia springs and/or EI3, EI4, } \\
\text { EI5, El7 springs }\end{array}$ & $\begin{array}{l}\text { Well construction in Plio-Pleistocene } \\
\text { aquifer (for Elatos - Kastro - Kalirahi - } \\
\text { Megaro common supply) }\end{array}$ \\
\hline 6 & Kastro & $\begin{array}{l}\text { Enrichment of domestic water supply } \\
\text { from Ks } 2 \text { and Ks } 3 \text { springs }\end{array}$ & $\begin{array}{l}\text { Well construction in Plio-Pleistocene } \\
\text { aquifer (for Elatos - Kastro - Kalirahi - } \\
\text { Megaro common supply) }\end{array}$ \\
\hline 7 & Kirakali & $\begin{array}{l}\text { Enrichment of domestic water supply } \\
\text { from Aetia springs and/or from Ki2 } \\
\text { spring }\end{array}$ & $\begin{array}{l}\text { Well construction in Plio-Pleistocene } \\
\text { aquifer (for Kirakali - Oropedio - Sidendro } \\
\text { - Rodia common supply) }\end{array}$ \\
\hline 8 & $\begin{array}{l}\text { Mega } \\
\text { Seirini }\end{array}$ & $\begin{array}{l}\text { Well construction in Plio-Pleistocene } \\
\text { aquifer }\end{array}$ & $\begin{array}{l}\text { Enrichment of domestic water supply from } \\
\text { Ms1 and Ms7 springs }\end{array}$ \\
\hline 9 & $\begin{array}{l}\text { Mikro } \\
\text { Seirini }\end{array}$ & $\begin{array}{l}\text { Well construction in Plio-Pleistocene } \\
\text { aquifer }\end{array}$ & \\
\hline 10 & Rodia & $\begin{array}{l}\text { Well construction in Plio-Pleistocene } \\
\text { aquifer (for Kirakali - Oropedio - } \\
\text { Sidendro - Rodia common supply) }\end{array}$ & \\
\hline 11 & Sidendro & $\begin{array}{l}\text { Enrichment of domestic water supply } \\
\text { from Si11 and Si13 springs }\end{array}$ & $\begin{array}{l}\text { Well construction in Plio-Pleistocene } \\
\text { aquifer (for Kirakali - Oropedio - Sidendro } \\
\text { - Rodia common supply) }\end{array}$ \\
\hline 12 & Kalirahi & $\begin{array}{l}\text { Enrichment of domestic water supply } \\
\text { from Ka2 and Ka4 springs }\end{array}$ & $\begin{array}{l}\text { Well construction in Plio-Pleistocene } \\
\text { aquifer (for Elatos - Kastro - Kalirahi - } \\
\text { Megaro common supply) }\end{array}$ \\
\hline 13 & Megaro & $\begin{array}{l}\text { Enrichment of domestic water supply } \\
\text { from Me6, Me4, Me1 and Me3 } \\
\text { springs }\end{array}$ & $\begin{array}{l}\text { Well construction in Plio-Pleistocene } \\
\text { aquifer (for Elatos - Kastro - Kalirahi - } \\
\text { Megaro common supply) }\end{array}$ \\
\hline 14 & Oropedio & $\begin{array}{l}\text { Enrichment of domestic water supply } \\
\text { from Or1, Or2, Or3 and Or4 springs }\end{array}$ & $\begin{array}{l}\text { Well construction in Plio-Pleistocene } \\
\text { aquifer (for Kirakali - Oropedio - Sidendro } \\
\text { - Rodia common supply) }\end{array}$ \\
\hline 15 & Anavrita & $\begin{array}{l}\text { Enrichment of domestic water supply } \\
\text { from An1, An4 and An5 springs }\end{array}$ & $\begin{array}{l}\text { Well construction in Plio-Pleistocene } \\
\text { aquifer (for Anavrita - Mavranaioi - } \\
\text { Mavronoros common supply) }\end{array}$ \\
\hline 16 & Mavranaioi & $\begin{array}{l}\text { Enrichment of domestic water supply } \\
\text { from Orliakas springs and/or Mn4, } \\
\text { Mn5 and Mn6 springs }\end{array}$ & $\begin{array}{l}\text { Well construction in Plio-Pleistocene } \\
\text { aquifer (for Anavrita - Mavranaioi - } \\
\text { Mavronoros common supply) }\end{array}$ \\
\hline 17 & Mavronoros & $\begin{array}{l}\text { Enrichment of domestic water supply } \\
\text { from Orliakas springs and/or from } \\
\text { Mr4, Mr5 and Mr6 springs }\end{array}$ & $\begin{array}{l}\text { Well construction in Plio-Pleistocene } \\
\text { aquifer (for Anavrita - Mavranaioi - } \\
\text { Mavronoros common supply) }\end{array}$ \\
\hline
\end{tabular}

In irrigation sector, where the exploitation level of water resources is very low, the alternative proposals presented below can increase the irrigating agricultural areas with:

- The construction of dams in Valtos and Doksaras streams, $3 \mathrm{Km}$ west of Kirakali village and $3 \mathrm{Km}$ west of Doksaras village respectively, with capacity of $1.5-2.0 \times 10^{6} \mathrm{~m}^{3}$ of water each, in order to exploit the surface waters of Grevenitis River and cover the water needs for an irrigating area of 6 
$\mathrm{Km}^{2}$ (Kirakali, Grevena, Doksara, Mavranaioi and Elatos). The total cost of the construction for each dam is estimated from 5 to 7 millions of $€(5,000,000-7,000,000 €)$, according to the local conditions.

- The exploitation of groundwater of Plio-Pleistocene aquifer with drills in order to cover the water needs for an irrigating area of $20 \mathrm{Km}^{2}$ (Mikro and Megalo Seirini, Kirakali, Grevena, Doksara, Mavranaioi, Mavronoros).

- The exploitation of the surface waters of Venetikos River located in the south side of Grevenitis basin in order to cover the water needs for an irrigating area of $4 \mathrm{Km}^{2}$ (Mavranaioi and Mavronoros).

The selection of the best alternative solutions both for drinking water supply and irrigation is not a simple matter. It should be made after the elaboration of specific studies (feasibility and implementation studies), which will examine in depth not only the works that must be done but also their construction cost, so as to choose the optimum solutions for radical exploitation and sustainable development of the area.

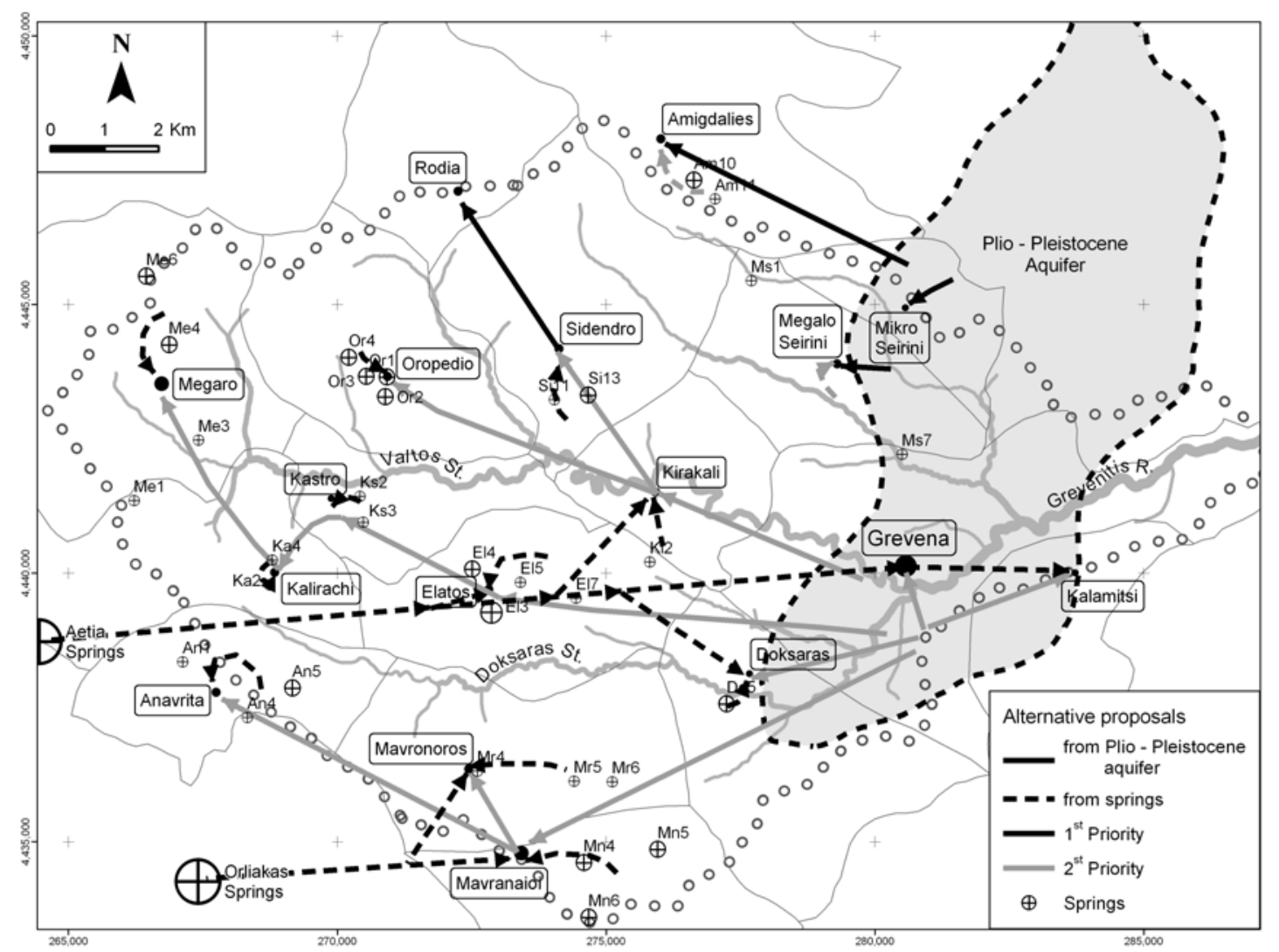

Figure 5. Thematic map with alternative proposals for development of water resources of the study area

\section{CONCLUSIONS}

The present study concerns the application of procedures for sustainable management and development of the water resources of the rural drainage basin of Grevenitis River, using Geographic Information Systems (GIS) technology.

- It reveals the potentiality of the area of hydrologic basin of Grevenitis River, to be self-reliant as far as the water resources are concerned. As a result, it can cover the area's total water needs. However, despite its self-reliability, so far the area covers its needs for water by the use of the water resources located outside the study area.

- It appoints the new perspectives for the sustainable development of the area, especially in agricultural field. This can happen by the exploitation of Grevenitis River surface water for agricultural use and of the Plio-Pleiostocene aquifer, mainly for drinking water needs. 
- It also emphasizes the contribution of GIS in rational management procedure of an area's water resources, along with the utilization of the geomorphologic, hydrologic, hydrogeological data, the development of data bases for the constant supervision, the direct plotting of various parameters and their fluctuations and the possibility to use and exploit these data at any time in order to create easily new thematic maps.

Based on the legislative and scientific framework concerning the quality of water intended for human consumption:

- $\quad$ some more actions are necessary in order to assist and improve water quality monitoring actions and ensure the protection of human health on a life-long basis (more parameters in drinking water analyses, frequent sampling and analyses),

- it is necessary to design and implement the proper protection -mainly precautionarymeasures of the drinking water resources, based on the study of hydrogeological and hydrological conditions of the catchment areas of water resources and the determination of protection zones: zone III - remote distance or remote surveillance zone concerning the hydrogeological drainage basin of drinking water resources, zone II - in vicinity with water sources or controlled zone concerning mainly the protection of water from microbiological pollution and zone I - direct protection or prohibited zone concerning the protection of the area closed to drinking water sources (water wells, water springs, etc) (Létourneur and Michel ,1971; Dimopoulos, 2007 \& 1983; Kallergis, 1986; EC, 1998 \& 2000; HL, 2003, 2001 \& 1986).

- it is necessary to design and implement a continuous monitoring program for the protection of quality of the Plio-Pleistocene groundwater aquifer of the area and of Grevenitis river surface waters,

- there is a need to plan and implement actions aiming to inform and aware the inhabitants (the final water users) on a regular basis.

However, the integrated management of the water resources requires the establishment of a local managerial authority as a part of a bigger unified managerial body (prefectorial, regional, national). This will ensure that the water resources and water consumption will be constantly estimated over the years, plans and programs for the rational exploitation of the water resources will be elaborated in order to achieve the integrated and sustainable development of the area.

Only through the full understanding of the various legal, policy, social and scientific issues involved the competent authorities will be able to use, manage and protect their water resources appropriately, effectively and in such a way that water of high quality is sufficient for present needs and is preserved for future generations.

\section{REFERENCES}

Antonopoulos B. (1993), Quality and pollution of groundwater, Publication Service of Aristotles University of Thessaloniki, Thessaloniki (in Greek).

Asraras Th. (1980), Quantitative geomorphological study of West part of Vertiskon mountain (Central Macedonia), Aristotle University of Thessaloniki, 1-214 (in Greek).

Balafutis X. (1977), Beitrag zur klimatischen Erforschung des Klimas in Mazedonien und West - Thrakien, Thessaloniki, 1-121.

Brunn J. (1956), Contribution a l' etude geologique du Pinde septentrionale et d'une partie de la Macedoine occidentale, Ann. Geol. Pays Hellen., 7, 1-358.

Cooper H.H. \& Jacob C.E. (1946), A generalized graphical method for evaluating formation constants and summarizing well-field history, Trans. Am. Geoph., Richmond, Va., Union 27, S. 526-534,

Davis S.N. and De Wiest R.J.M. (1967), Hydrogeology. John Wiley \& Sons, Inc. N. York, 1-463.

Dimopoulos, G. (2007), Geological studies of Technical Works - Hydrogeological Studies, Kiriakidis Publ., Thessaloniki, 61-155 (in Greek).

Dimopoulos G. (1998), Water Resources Management : 1st Conference for development perspective of Thasos island, Prinos of Thasos (Greece) 1998, Proceedings, vol. 1, 236-247 (in Greek). 
Dimopoulos G. (1995), Investigation and Management of Water Resources, Aristotles University of Thessaloniki, 1-217 (in Greek).

Dimopoulos G. (1983), Applied Geology. Vol. 1, Hydrogeology, Thessaloniki, 1-428 (in Greek).

EC (2000), Establishing a framework for Community action in the field of water policy, Directive 2000/60/EC, Official Journal L327/22.12.2001, European Community, 1-72.

EC (1998), The quality of water intended to human consumption, Directive 1998/83/EC, Official Journal L330/05.12.1998, European Community, 32-54.

ESRI (2004), ARC GIS program manuals, Redlands California, USA.

ESRI (1994), ARC INFO program manuals. Environmental Systems Research Institute, Inc., Redlands California, USA.

Georgotas N. (1983), Evaluation and management of water resources, Scientific Bulletin of Technica Chronica, Technical Chamber of Greece, Athens, 21-28 (in Greek).

$\mathrm{HL}$ (2007), Determination of measures and procedures for the integrated protection and management of water resources in compliance with Directive 2000/60/EC, Presidential Decree 51/2007, Official Journal A' 54/08.03.2007, Athens, Hellenic Legislation (in Greek).

HL (2003), Protection and management of water resources - compliance with Directive 2000/60/EC, Law 3199/2003, Official Journal A'/280/09.12.2003, Athens, Hellenic Legislation (in Greek).

HL (2001), Quality of water intended for human consumption in compliance with Directive 1998/83/EC, Interministerial Decree Y2/2600/2001, Official Journal B'/892/11.07.2001, Athens, Hellenic Legislation (in Greek).

HL (1987), Management of water resources. Law 1739/1987, Official Journal A'/201/20.11.1987, Athens, Hellenic Legislation (in Greek).

HL (1986), Protection of environment. Law 1650/1986, Official Journal A'/160/16.11.1986, Athens, Hellenic Legislation (in Greek).

HMEPW (2003), Study of Regional framework for spatial planning and sustainable development of West Macedonia Region, Hellenic Ministry for Environment and Public Works, Athens, 1-236 (in Greek).

HMIET (1987), Meteorological and rain-gauge stations of Greece. Division of water resources, Hellenic Ministry for Industry, Energy and Technology, Athens, 1-83 + 13 maps (in Greek).

Horton R. (1945), Erosional development of streams and their drainage basins: Hydrophysical approach to quantitative morphology, Geol. Soc. Amer. Bull., 56, 275-370.

Howard D. (1967), Drainage analysis in geologic interpretation: a summation, Bull. Amer. Assoc. Petrol. Geol., vol. 51 (11), 2246-2259.

Kallergis G. (1986), Applied Hydrogeology, Published from Technical Chamber of Greece, Athens, Vol.1, 1-707, Vol. 1-681 (in Greek).

Kallergis G. (1973), Hydrogelogical Investigation of West Thessaly Basin - Greece, Institute of geological and Mineral Investigation of Greece, athens (in Greek)

Létourneur J. and Michel R. (1971), Civil Engineering Geology (Géologie du Genie Civil), Armand-Colin, Paris, 273-435.

Mavridis A. \& Kelepertzis A. (1993), Geological map of "Knidi" sheet in scale 1:50,000, IGME, Athens.

Mitchell A. (1999), The ESRI guide to GIS analysis: Vol.1, Geographic patterns \& relationships, Environmental Systems Research Institute, Inc., Redlands California, USA, 1-186.

Mountrakis D. (1985), Geology of Greece, Univ. Studio Press, Thessaloniki, 1-205 (in Greek).

Mouratidis I. (2005), Contribution of Geographic Information Systems (GIS) technology in Water Resources Management of Grevenitis river basin in Grevena Prefecture (Greece), Ph.D. Thesis, Department of Geology, Aristotle University of Thessaloniki (in Greek).

RWM (2001), Regional Development Program 2000-2006, Region of West Macedonia, Kozani, 1-65 (in Greek).

Savoyat E. \& Monopolis D. (1972), Geological map of "Grevena" sheet in scale 1:50,000, IGME, Athens.

Soulios G. (1981), General Hydrogeology, vol. 1, Univ. Studio Press, Thessaloniki, 1-332 (in Greek).

Soulios G. (1981), General Hydrogeology, vol. 2, Paratiritis Publ., Thessaloniki, 1-286 (in Greek).

Soulios G. (2004), General Hydrogeology, vol. 3 : Groundwater Reservoirs and Management. Kiriakidis Publ., Thessaloniki, 1-250 (in Greek).

Stamos A. \& Zampokas N. (1995), Hydrogeological map of Grevena Prefecture in scale 1:100.000, IGME, Kozani Brance (in Greek).

Stamos A., Zampokas N., Mathaiopoulos D. \& Pafilis E. (2001), Monitoring of water quality and hydrogeological study of West Macedonia water resources, IGME, Kozani Brance, (in Greek).

Stamos A. (2001), The shallow aquifer of Aetia basin and the optimum evaluation for water supply of Grevena municipality, IGME, Kozani Brance, 1-19 (in Greek). 
Stournaras G. (2006), Water: Environmental aspect and course, Tziola Ed., Thessaloniki, 77-174, 495650 (in Greek).

Strahler A. (1952), Hypsometric (area-altitude) analysis of erosional topography, Geol. Soc. Amer. Bull., $63,1117-42$.

Strahler A. (1964), Quantitative geomorphology of drainage basins and channel networks, In CHOW, V.T., (Ed) Handbook of Applied Hydrology, New York, Section 14, 54.

Thornthwaite C.W. \& Mather J.R. (1955), The water balance, Drexel Inst. Technol. Publ. Climat., Centerton, N.J., VIII, Nr. 1.

Thornthwaite C.W. \& Mather J.R. (1957), Instructions and tables for computing potential evaportranspiration and the water balance. Publication in Climatology, New Jersey., vol. 10, no 3.

Tsakiris G. (1995), Water Resources: I. Technical Hydrology, Symmetria Editions, Athens, 579-618 (in Greek).

USEPA (2006), National Primary Drinking Water Regulations: Ground Water Rule - Final Rule, US Environmental Protection Agency, 1-88.

USPHS (1962), Drinking water standards - revised 1962, US Public Health Service, Washington, D.C., no $956,1-61$.

US Salinity Laboratory (1954), Diagnosis and improvement of saline and alkaline soils, US Department Agriculture Handbook, 1-60.

Vamvaka A., Kilias A. \& Mountrakis D. (2004), Geometry and structural evolution of the Mesohellenic Trough. A new approach: 5th International Symposium on Eastern Mediterranean Geology, Structural Geology, Stratigraphy and Tectonics of the Eastern Mediterranean, Proceedings, vol. 1, 209-212.

WHO (2006), Protecting groundwater for health: Managing the quality of drinking-water sources, World Health Organization, Geneva, 1-697.

WHO (2006), Guidelines for drinking water quality. World Health Organization, Geneva, 1-595.

WHO (1993), Guidelines for Drinking-water Quality, Vol. 1, Recommendations, (2nd ed.), World Health Organization, Geneva.

Zeiler M. (1999), Modeling our World: The ESRI guide to geodatabase design, Environmental Systems Research Institute, Inc., Redlands California, USA, 1-195. 